\title{
Position and Speed Sensorless Control System of Permanent Magnet Synchronous Motor with Parameter Identification
}

\author{
Shigeo Morimoto Senior Member (Osaka Prefecture University, morimoto@eis.osakafu-u.ac.jp) \\ Akihide Shimmei Student Member (Osaka Prefecture University, shinmei@eis.osakafu-u.ac.jp) \\ Masayuki Sanada Member (Osaka Prefecture University, sanada@eis.osakafu-u.ac.jp) \\ Yoji Takeda Senior Member (Osaka Prefecture University, takeda@eis.osakafu-u.ac.jp)
}

Keywords: permanent magnet synchronous motor, parameter identification, least-squares method, sensorless control, dead-time

This paper proposes the sensorless control system of PMSM that doesn't need parametric information beforehand. The parameters of PMSM drive system including inverter are identified at standstill and operating condition.

Fig. 1 shows the proposed sensorless control system of PMSM with parameter identification. The novel $d-q$ model of PMSM drive system including the inverter, which corresponds to the part enclosed with the broken line in Fig. 1, is given by

$$
\begin{gathered}
{\left[\begin{array}{c}
v_{\text {d_ref }} \\
v_{q_{-} r e f}
\end{array}\right]=\left[\begin{array}{cc}
R_{s}+p L_{d} & -\omega L_{q} \\
\omega L_{d} & R_{s}+p L_{q}
\end{array}\right]\left[\begin{array}{c}
i_{d} \\
i_{q}
\end{array}\right]+\left[\begin{array}{c}
0 \\
\omega \psi_{a}
\end{array}\right]+\Delta V\left[\begin{array}{l}
D_{d} \\
D_{q}
\end{array}\right]} \\
{\left[\begin{array}{c}
D_{d} \\
D_{q}
\end{array}\right]=\sqrt{\frac{2}{3}}\left[\begin{array}{ccc}
\cos \theta & \cos \left(\theta-\frac{2 \pi}{3}\right) & \cos \left(\theta+\frac{2 \pi}{3}\right) \\
-\sin \theta & -\sin \left(\theta-\frac{2 \pi}{3}\right) & -\sin \left(\theta+\frac{2 \pi}{3}\right)
\end{array}\right]\left[\begin{array}{l}
\operatorname{sgn}\left(i_{u}\right) \\
\operatorname{sgn}\left(i_{v}\right) \\
\operatorname{sgn}\left(i_{w}\right)
\end{array}\right],}
\end{gathered}
$$

where $v_{\text {d_ref }}, v_{q_{-} r e f}$ : voltage references, $\Delta V$ : voltage error due to inverter, $R_{s}$ : resistance consisting of the armature resistance, wiring resistance and on-resistance of the switching device.

The parameters in the model of (1) are identified at standstill and operating condition. At first, the initial rotor position is estimated by a signal injection sensorless scheme, in which the machine parameters are not required. After the initial position has been estimated, $R_{s}, \Delta V, L_{d}$ and $L_{q}$ are identified at standstill. Fig. 2 shows the experimental identification performance of $L_{d}, L_{q}$ and $\Delta V$ at standstill. The parameters are rapidly identified and good performance is obtained.
After the motor starts by the signal injection sensorless control, the sensorless scheme changes to an extended EMF estimation based scheme. The identified parameters of $R_{s}, \Delta V, L_{d}$ and $L_{q}$ are used in such sensorless control. The magnet flux-linkage $\psi_{a}$, which can not be identified at standstill, is identified under the sensorless operation at medium and high speeds. The effectiveness of the proposed method is verified by several experimental results.
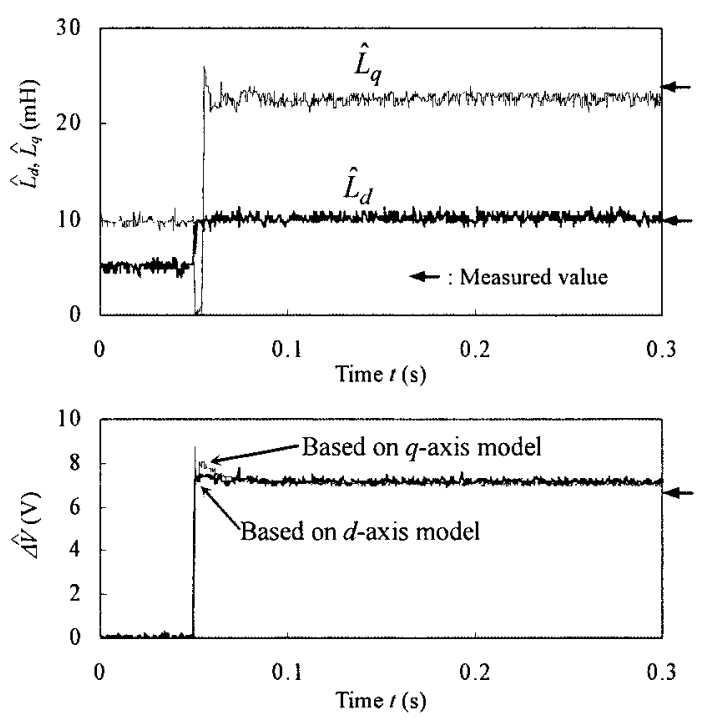

Fig. 2. Identification characteristic of $L_{d}, L_{q}$ and $\Delta V$

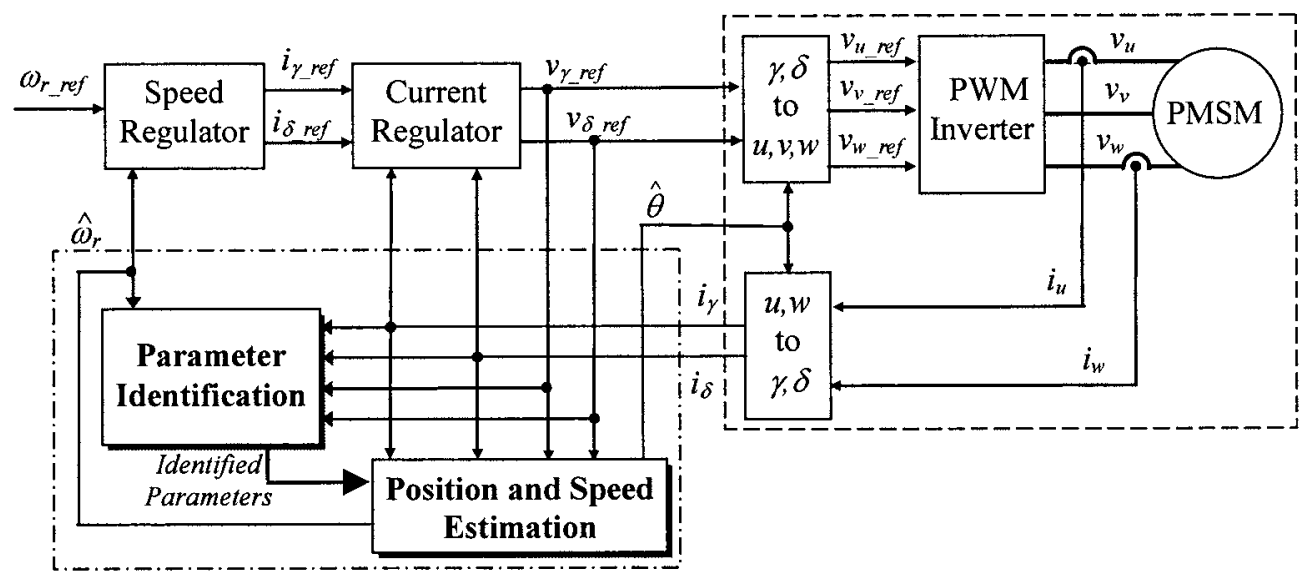

Fig. 1. Sensorless control system of PMSM with parameter identification 


\title{
パラメータ同定機能を持つ永久磁石同期モータの 位置・速度センサレス制御システム
}

\author{
上級会員 森本 茂雄* 学生員 神名 玲秀* \\ 正 員 真田 雅之* 上級会員 武田 洋次*

\section{Position and Speed Sensorless Control System of Permanent Magnet Synchronous Motor with Parameter Identification} \\ Shigeo Morimoto*, Senior Member, Akihide Shimmei*, Student Member, Masayuki Sanada*, Member, \\ Yoji Takeda*, Senior Member
}

The model parameters of permanent magnet synchronous motor (PMSM) are required for a high-performance control and a model based sensorless control. This paper proposes the sensorless control system of PMSM that doesn't need parametric information beforehand. The parameters of PMSM drive system including inverter are identified at standstill and operating condition. At first, the initial rotor position is estimated by a signal injection sensorless scheme, in which the machine parameters are not required. After the initial position has been estimated, the resistance including on-resistance of IGBT, the voltage error caused by dead-time of inverter, $d$-axis and $q$-axis inductances are identified at standstill. After the motor starts by the signal injection sensorless control, the sensorless scheme changes to an extended EMF estimation based scheme. The estimated parameters of resistance, $d$-axis and $q$-axis inductances are used in such sensorless control. The magnet flux-linkage, which can not be estimated at standstill, is identified under the sensorless operation at medium and high speeds. The effectiveness of the proposed method is verified by several experimental results.

キーワード：永久磁石同期モータ，パラメータ同定，最小二乗法，センサレス制御，デッドタイム

Keywords: permanent magnet synchronous motor, parameter identification, least-squares method, sensorless control, dead-time

\section{1. まえがき}

永久磁石同期モー夕 (PMSM) は高効率で制御性の良い モータとして広く使用されている。PMSMの高性能運転に は，速度や負荷状態に応じた適切な電流べクトルの制御が 必要であり，各種制御法が提案されている。その制御アル ゴリズムはモータモデルに基づき導出されることが多く, 高性能制御の実現にはモータパラメータの把握が必要であ る。そこで，モータパラメータの計測法やオンライン同定 法が検討されている (1) (6)。また, PMSMの制御には位置検 出が必要であり, センサの価格, 耐環境性, 信頼性などの 観点からセンサレス制御の要求が強く盛んに研究されてい る (7) (10)。PMSMのセンサレス制御法としては，インダク タンスの位置依存性を利用する方式と速度起電力（または 鎖交磁束）を利用する方式とに大別できる ${ }^{(10)}$ 。前者は，高

\footnotetext{
* 大阪府立大学大学院工学研究科

干 599-8531 大阪府堺市学園町 1-1

Graduate School of Engineering, Osaka Prefecture University

1-1, Gakuen-cho, Sakai, Osaka 599-8531
}

周波の電圧または電流を印加するもので, 停止時でも位置 推定が可能となる方式であるが，余分な電流を流すことに なり, 効率低下や騒音などの問題が生じる場合がある。一 方, 後者の速度起電力を基にしたセンサレス制御は, モー 夕停止時，極低速時には使用できないものの，特別な信号 の印加が不要でモー夕に供給する電圧および検出した電流 の情報のみによって位置推定が可能である。しかし，その 推定アルゴリズムはモータモデルを基にしているためモデ ルパラメータを必要とする(7)(8)。さらに，センサレス制御な どで用いるモー夕電圧情報は検出值ではなく指令值の場合 が多く, デッドタイムや半導体デバイスの電圧降下などイ ンバー夕部で生じる指令值と実際值の誤差が推定誤差を引 き起こす。また, 電流制御性能にもデッドタイムは悪影響 を及ぼすので，その補償法が検討されている ${ }^{(11)}$ 。

PMSM のパラメータ同定およびセンサレス制御について は多数の研究報告がなされているが，位置センサを用いず モータパラメータを起動前あるいは運転中に同定し, セン サレス制御を実現する手法の提案 ${ }^{(2)(4)}$ は殆どない。本論文 では，センサレス制御で用いるモータシステムのパラメー 
夕を位置センサを用いずに起動前に同定し，同定したパラ メータを用いて位置・速度センサレス制御を実現するモー タパラメータの事前情報を必要としないセンサレス制御シ ステムを提案している。

同定対象として，モー夕本体のみではなく電圧指令值を 入力とするインバータを含む新たな PMSM 駆動システム のモデルを提案する。そのモデルに含まれるパラメータで ある抵抗， $d$ 軸インダクタンス, $q$ 軸インダクタンス, 磁石 による電機子鎖交磁束および電圧指令值と実電圧との電圧 誤差を運転状態に対応した適切な同定モデルを用いて同定 する。すなわち，停止時の電流一定状態に打いて抵抗と電 圧誤差を，停止時の電流が変化する過渡状態でインダク夕 ンスと電圧誤差を，モータが回転している状態で電機子鎖 交磁束を同定する。パラメー夕同定を位置・速度センサレ スで実現する具体的な手順は次の通りである ${ }^{(12)}$ 。まず，電 源投入時にモータパラメータを必要としない高周波印加方 式の位置推定法で停止位置を推定し，その推定位置を用い て停止時に同定可能なパラメー夕を同定する。つぎに，同 定したパラメータを搪張誘起電圧推定方式のセンサレス制 御に使用し，センサレス駆動を行う。本センサレス制御は 停止時に同定できない磁石磁束の值を必要としない特徵が ある。さらに，センサレス駆動の状態で，停止時に同定で きない磁石磁束を同定する。全モータパラメー夕を同定す ることで運転状態に応じた電流べクトルの最適な制御が可 能となる。提案手法の有效性を実験で確認している。

\section{2. インバータを含むPMSM のモデル}

図 1 に標準的な PMSM 制御システムの構成図を示す。制 御対象である PMSM の $d-q$ 回転座標上での電気系モデル は (1) 式で与えられる。

$\left[\begin{array}{l}v_{d} \\ v_{q}\end{array}\right]=\left[\begin{array}{cc}R_{a}+p L_{d} & -\omega L_{q} \\ \omega L_{d} & R_{a}+p L_{q}\end{array}\right]\left[\begin{array}{c}i_{d} \\ i_{q}\end{array}\right]+\left[\begin{array}{c}0 \\ \omega \psi_{a}\end{array}\right]$

ただし $, i_{d}, i_{q}$ : 電機子電流の $d, q$ 軸成分, $v_{d}, v_{q}$ : 電機子電圧の $d, q$ 軸成分, $\omega$ : 回転角速度 $($ 電気 角), $\theta$ : 回転子位置 (電気角) , $\psi_{a}$ : 永久磁石によ る電機子鎖交磁束, $R_{a}:$ 電機子抵抗, $L_{d}, L_{q}: d$, $q$ 軸インダクタンス, $p:$ 微分演算子

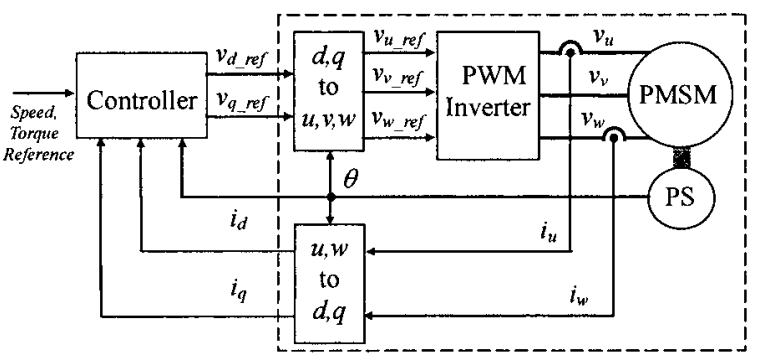

図 1 標準的な PMSM 制御システムの構成図

Fig. 1. Block diagram of standard PMSM control system.
この $d-q$ 軸モデルを基にして制御系が設計され，速度やト ルク指令と検出電流拉よび速度・位置情報よりモー夕に印 加する電圧指令が決まり，PWM インバータによりモー夕 が駆動される。 $d-q$ 軸モデルを基にして制御系を考えたと き, 検出値は $d, q$ 軸電流 $i_{d}, i_{q}$ であり, 出力は $d, q$ 軸電 圧指令 $v_{\text {d_ref }}, v_{\text {q_ref }}$ となる。このとき, 制御対象はモー夕 のみでなく PWM インバー夕も含む図 1 の破線部となる。 そこで，破線部のモデル化を考える。

モータに印加される $\mathrm{u}$ 相電圧 $v_{u}$ と指令值 $v_{u_{-} r e f}$ との関係 は $\mathrm{u}$ 相電流 $i_{u}$ の極性に依存した電圧および抵抗成分を考慮 すると (2) 式で表すことができる。他の相も同様である。

$$
v_{u}=v_{u_{-} r e f}-\Delta R i_{u}-\Delta V \cdot \operatorname{sgn}\left(i_{u}\right) \cdot
$$

ここで, $\Delta R$ はスイッチング素子のオン抵抗や配線抵抗な どに相当し， $\Delta V$ はインバータのデッドタイム及びスイッ チング素子のオン電圧による電圧誤差に相当する。従って, $d-q$ 座標上での電圧指令值とモータ印加電圧の関係は次式 となる。

$$
\begin{aligned}
& {\left[\begin{array}{l}
v_{d} \\
v_{q}
\end{array}\right]=\left[\begin{array}{l}
v_{\text {d_ref }} \\
v_{\text {q_ref }}
\end{array}\right]-\Delta R\left[\begin{array}{l}
i_{d} \\
i_{q}
\end{array}\right]-\Delta V\left[\begin{array}{l}
D_{d} \\
D_{q}
\end{array}\right] \ldots \ldots \ldots \ldots \ldots} \\
& {\left[\begin{array}{l}
D_{d} \\
D_{q}
\end{array}\right]=\sqrt{\frac{2}{3}}\left[\begin{array}{ccc}
\cos \theta & \cos \left(\theta-\frac{2 \pi}{3}\right) & \cos \left(\theta+\frac{2 \pi}{3}\right) \\
-\sin \theta & -\sin \left(\theta-\frac{2 \pi}{3}\right) & -\sin \left(\theta+\frac{2 \pi}{3}\right)
\end{array}\right]\left[\begin{array}{l}
\operatorname{sgn}\left(i_{u}\right) \\
\operatorname{sgn}\left(i_{i}\right) \\
\operatorname{sgn}\left(i_{w}\right)
\end{array}\right]}
\end{aligned}
$$

(1)，(3) 式より，本論文で同定対象とするインバータを含 むモータモデル（図1 中の破線部）は次式で表される。

$$
\left[\begin{array}{l}
v_{d \text { dref }} \\
v_{q_{-} \text {ref }}
\end{array}\right]=\left[\begin{array}{cc}
R_{s}+p L_{d} & -\omega L_{q} \\
\omega L_{d} & R_{s}+p L_{q}
\end{array}\right]\left[\begin{array}{c}
i_{d} \\
i_{q}
\end{array}\right]+\left[\begin{array}{c}
0 \\
\omega \psi_{a}
\end{array}\right]+\Delta V\left[\begin{array}{c}
D_{d} \\
D_{q}
\end{array}\right]
$$

ここで, $R_{s}=R_{a}+\Delta R$ であり, モータの巻線抵抗にスイッ チング素子のオン抵抗や配線抵抗などを含んだ制御側から 見たトータル抵抗を表す。

(5) 式をサンプリング周期 $T_{s}$ で離散化して次式を得る。 (6) 式を $d$ 軸モデル，(7) 式を $q$ 軸モデルと呼ぶことにする。

$$
\begin{aligned}
i_{d}(k+1)= & \left(1-\frac{R_{s}}{L_{d}} T_{s}\right) i_{d}(k)+\frac{L_{q}}{L_{d}} T_{s}\left(\omega(k) i_{q}(k)\right) \\
& +\frac{T_{s}}{L_{d}} \cdot v_{d \_r e f}(k)-\frac{T_{s}}{L_{d}} \cdot \Delta V \cdot D_{d}(k) \ldots \ldots \\
i_{q}(k+1)= & \left(1-\frac{R_{s}}{L_{q}} T_{s}\right) i_{q}(k)-\frac{L_{d}}{L_{q}} T_{s}\left(\omega(k) i_{d}(k)\right) \\
& -\frac{\psi_{a}}{L_{q}} T_{s} \cdot \omega(k)+\frac{T_{s}}{L_{q}} \cdot v_{q-r e f}(k) \\
& -\frac{T_{s}}{L_{d}} \cdot \Delta V \cdot D_{q}(k) \ldots \ldots \ldots \ldots \ldots
\end{aligned}
$$

\section{3. パラメータ同定法}

本論文のパラメータ同定には, 逐次形最小二乗アルゴリ ズムを用いる。同定対象のモデルを（8) 式としたとき，(9) 
式によりパラメータ $\Theta$ が同定できる。

$Y(k)=\Theta^{T} Z(k)$

$$
\hat{\Theta}(k)=\hat{\Theta}(k-1)
$$

$$
+\frac{\boldsymbol{P}(k-1) Z(k)}{\lambda+Z^{T}(k) \boldsymbol{P}(k-1) Z(k)}\left(Y(k)-Z^{T}(k) \hat{\Theta}(k-1)\right)
$$

$$
\boldsymbol{P}(k)=\frac{1}{\lambda}\left(\boldsymbol{P}(k-1)-\frac{\boldsymbol{P}(k-1) Z(k) Z^{T}(k) \boldsymbol{P}(k-1)}{\lambda+Z^{T}(k) \boldsymbol{P}(k-1) Z(k)}\right)
$$

ただし， $\Theta:$ パラメータベクトル，P:行列ゲイン，

$Y:$ 出力, $Z:$ 信号ベクトル, $\lambda:$ 忘却係数

(6)，（7）式を同定時の運転条件により変形し，(8) 式に対 応させることでパラメー夕を同定する。

まず，起動前の停止状態においてパラメータを同定する。 停止時の同定モデルは (6), (7) 式に打いて $\omega(k)=0$ とする ことで得られ，例えば $d$ 軸モデルは (6) 式より (11) 式とな る。なお，同定モデルの表記は (8) 式に対応しており，左 辺が出力 $Y$, 右辺がパラメータベクトル $\Theta$ と信号ベクトル $Z$ の積である。（後に示す (12)，(13)，(14) 式も同様）

$$
i_{d}(k+1)=\left[\begin{array}{c}
1-\frac{R_{s}}{L_{d}} T_{s} \\
\frac{T_{s}}{L_{d}} \\
-\frac{T_{s}}{L_{d}} \Delta V
\end{array}\right]^{T}\left[\begin{array}{c}
i_{d}(k) \\
v_{d \_r f}(k) \\
D_{d}(k)
\end{array}\right] .
$$

上式に基づき, $d$ 軸電流， $d$ 軸電圧指令および $D_{d}$ より未知 パラメータが同定でき， $R_{s}, L_{d}, \Delta V$ の同定が可能となる。 しかし，パラメータベクトルの第 1 項 $\left(1-R_{s} T_{s} / L_{d}\right)$ が 1 に近い場合，この項の同定精度がある程度高くても，それ から逆算して得る $R_{S}$ の同定精度は悪くなる。そこで，まず 電流一定の定常時を想定し， $i_{d}(k+1)=i_{d}(k)$ として得られ る次式より $R_{S}$ と $\Delta V$ を同定する。

$$
v_{d \_r e f}(k)=\left[\begin{array}{c}
R_{s} \\
\Delta V
\end{array}\right]^{T}\left[\begin{array}{c}
i_{d}(k) \\
D_{d}(k)
\end{array}\right]
$$

$R_{s}$ が同定できた後， $d$ 軸同定モデルは (11) 式から (13) 式 のように変形でき， $L_{d}$ と $\Delta V$ が同定できる。同様にして $q$ 軸モデルを用いて $L_{q}$ と $\Delta V$ が同定できる。

$$
i_{d}(k+1)-i_{d}(k)=\left[\begin{array}{c}
\frac{T_{s}}{L_{d}} \\
-\frac{T_{s}}{L_{d}} \Delta V
\end{array}\right]^{T}\left[\begin{array}{c}
v_{d \_r e f}(k)-R_{s} i_{d}(k) \\
D_{d}(k)
\end{array}\right]
$$

以上ょり，磁石磁束 $\psi_{a}$ 以外のパラメー夕は停止時に同 定可能となる。停止時に同定できない $\psi_{a}$ は，運転状態に おいて他のパラメータが既知であることから (7) 式の $q$ 軸 同定モデルを変形して次式に基づいて同定する。

$$
\begin{gathered}
\frac{L_{q}}{T_{s}}\left\{i_{q}(k+1)-i_{q}(k)\right\}+R_{s} i_{q}(k)+L_{d} \omega(k) i_{d}(k) \\
\quad-v_{q_{-} r f}(k)+\Delta V D_{q}(k)=-\psi_{a} \cdot \omega(k) \cdots \cdots
\end{gathered}
$$

\section{4. 位置・速度センサレス制御法}

位置・速度センサレス制御方式として多数の方法が提案 されている ${ }^{(10)}$ 。本論文では，通常の運転領域においては回 転座標上の拡張誘起電圧に基づくモータモデルを用いた拡 張誘起電圧推定方式のセンサレス制御を適用する(7)。本方 式では，拡張誘起電圧を推定する際にモータパラメー夕を 必要とするが, 停止時に同定できない磁石磁束 $\psi_{a}$ を必要と しない特長がある。前章で述べたように，停止時に $\psi_{a}$ を 除く全てのパラメータが同定できるため拡張誘起電圧推定 方式のセンサレス制御が適用できる。

回転座標の $d-q$ 軸から偏差 $\theta_{e}$ を持つ推定軸（ $\gamma-\delta$ 軸）に おける搪張誘起電圧を用いた IPMSM のモデルは次式とな る(7)。

$$
\begin{aligned}
& {\left[\begin{array}{l}
v_{\gamma} \\
v_{\delta}
\end{array}\right]=\left[\begin{array}{cc}
R_{a}+p L_{d} & -\omega L_{q} \\
\omega L_{q} & R_{a}+p L_{d}
\end{array}\right]\left[\begin{array}{l}
i_{\gamma} \\
i_{\delta}
\end{array}\right]+\left[\begin{array}{c}
e_{\gamma} \\
e_{\delta}
\end{array}\right] \ldots \ldots} \\
& {\left[\begin{array}{c}
e_{\gamma} \\
e_{\delta}
\end{array}\right]=E_{e x}\left[\begin{array}{c}
-\sin \theta_{e} \\
\cos \theta_{e}
\end{array}\right]+(\hat{\omega}-\omega) L_{d}\left[\begin{array}{c}
-i_{\delta} \\
i_{\gamma}
\end{array}\right] \ldots \ldots \ldots} \\
& E_{e x}=\omega\left\{\left(L_{d}-L_{q}\right) i_{d}+\psi_{a}\right\}-\left(L_{d}-L_{q}\right)\left(p i_{q}\right) \ldots \ldots
\end{aligned}
$$

(15) 式を基に文献(7) で示されている外乱オブザーバで拡 張誘起電圧 $e_{\gamma}, e_{\delta}$ を推定する。このとき, モータパラメー 夕のひとつである $\psi_{a}$ は不要である。推定した拡張誘起電 圧より $d-q$ 軸と $\gamma-\delta$ 軸との軸誤差の推定值 $\hat{\theta}_{e}$ は

$$
\hat{\theta}_{e}=\tan ^{-1}\left(-\frac{\hat{e}_{\gamma}}{\hat{e}_{\delta}}\right)
$$

で得られる。この推定位置誤差が零になるように次式のよ うに補正して推定速度 $\hat{\omega}$ を得て, さらに推定速度を積分し て推定位置 $\hat{\theta}$ を得る。

$$
\hat{\omega}=\left(K_{p}+\frac{K_{i}}{s}\right) \hat{\theta}_{e} .
$$

上記方式では停止時や低速時の位置推定が困難なため, インダクタンスの位置依存性を利用した位置推定手法を用 いる。インダクタンスの位置依存性を利用した位置推定法 では，位置推定にモータパラメータを必要としない方式が 多く，モータパラメータが不明な初期状態に打いても位置 推定は可能である。本論文では，高周波電流注入方式を用 いた (9)。本方式では，推定 $\gamma-\delta$ 軸上に (20) 式のような高周 波電流を流す。

$$
\left[\begin{array}{l}
i_{\gamma} \\
i_{\delta}
\end{array}\right]=\left[\begin{array}{c}
I_{h} \sin \theta_{h} \\
0
\end{array}\right], \quad \theta_{h}=\omega_{h} t .
$$

このとき, $\delta$ 軸上の電圧から中心周波数 $\omega_{h}$ のバンドパス フィル夕により取り出した高周波電圧成分 $v_{d h}$ は (15) 式よ り次式となり，位置誤差情報 $\theta_{e}$ を含む。

$$
\begin{aligned}
v_{\delta h}= & \omega L_{q} I_{h} \sin \theta_{h}+E_{\text {exh }} \cos \theta_{e} \\
+ & (\hat{\omega}-\omega) L_{d} I_{h} \sin \theta_{h} \ldots \ldots \ldots . \\
E_{\text {exh }}= & {\left[\omega\left(L_{d}-L_{q}\right)\left(I_{h} \sin \theta_{h}\right) \cos \theta_{e}\right.} \\
& +\left(L_{d}-L_{q}\right) I_{h}\left\{\omega_{h} \cos \theta_{h} \sin \theta_{e}\right. \\
& \left.\left.+(\omega-\hat{\omega}) \sin \theta_{h} \cos \theta_{e}\right\}\right] \ldots \ldots
\end{aligned}
$$


これに $\cos \theta_{h}$ をかけ，ローパスフィルタにより直流成分を 抽出すると次式のようになり, 位置誤差 $\theta_{e}$ に依存した信号 が得られる。

$$
v_{c l}=\frac{L_{d}-L_{q}}{4} I_{h} \omega_{h} \sin 2 \theta_{e}
$$

拡張誘起電圧推定法の場合と同様に $v_{c l}$ が零になるように補 正することで推定速度，推定位置を得る。このとき，(23) 式より分かるように $L_{d}$ と $L_{q}$ に差があれば良くそれらの值 は必要としない。また，その他のモータパラメータも不要 で， $v_{\delta h}$ をフィル夕処理することで位置誤差 $\theta_{e}$ に依存した 信号が得られる。

なお，上記位置推定アルゴリズムの説明では実電圧を入 力とするモータの $d-q$ 軸モデルを用いたが，実際には (5) 式を基にセンサレス制御を行うため電圧は電圧指令值とな り，抵抗は $R_{s}$ を使用する。ただし， $\Delta V$ の影響は，後述の ように同定した $\Delta V$ を用いてフィードフォワード補償する ためセンサレス制御で用いるモデルでは考慮しない。

\section{5. 実験結果}

〈5・1〉 実験システムと同定フロー

実験システムの 構成と諸元を図 2 , 表 1 に示す。供試機は埋込磁石同期モー 夕（IPMSM）であり，表中のモー夕定数はオフラインで測 定した值 ${ }^{(1)}$ である。ただし， $R_{S}$ はインバータの DC リンク からモータ側の抵抗值を測定して算出し， $\Delta V$ は，デッド タイム，デバイスのオン・オフ時間などより計算した值 ${ }^{(11)}$ である。

モータ制御部（速度制御，電流制御）は一般的な PMSM の制御システムの構成であり，速度制御と電流制御のサン プリング周期はそれぞれ $5 \mathrm{~ms} ， 0.1 \mathrm{~ms}$ である。図 1 中の一 点鎖線で囲った部分が通常の制御システムに追加する位置・ 速度推定部とパラメータ同定部である。位置・速度推定部 は, 推定座標 $(\gamma-\delta$ 座標 $)$ 上の電圧指令および検出電流よ り，4 章で述べた手法で位置・速度を推定する。パラメー 夕同定部では推定した位置・速度情報と電圧指令および検 出電流より 3 章で述べた同定法でパラメータを同定する。 従って，3 章中の同定モデルにおける $d-q$ 座標上の変数は $\gamma-\delta$ 座標上の変数に, 位置, 速度は, それらの推定值に置 き換えることになる。提案同定手法では, 運転状態によっ て同定モデルを (12)〜(14) 式のように分けているため同時 に同定するパラメータは最大でも2つであり，同定信号と しては単純な方形波を用いた。また，その周期は応答速度 の数倍程度としている。また，全ての実験において，(9), (10) 式における行列ゲインの初期值を $\boldsymbol{P}(0)=10 \boldsymbol{I}(\boldsymbol{I}$ : 単位 行列), 忘却ゲインを $\lambda=0.9995$ と設定している。位置 · 速度推定と停止時のパラメータ同定のサンプリング周期は 電流制御周期と同じ $0.1 \mathrm{~ms}$ である。運転時の $\psi_{a}$ の同定周 期は $10 \mathrm{~ms}$ に設定している。PMSM 制御や同定，センサレ ス制御の計算は全て DSP（TI 社製 TMS320C32）で行って いる。

パラメータ同定およびセンサレス駆動は以下の手順で 行う。

（1）初期位置推定：高周波電流注入方式により停止位 置を推定する。

（2）停止時のパラメータ同定：推定した停止位置の情 報を用いて，停止時の同定法で $R_{s}, L_{d}, L_{q}, \Delta V$ を同定す る。また，同定した $\Delta V$ を用いて電圧指令值を補正する。

（3） センサレス駆動：高周波電流注入方式で起動後, 停 止時に同定したパラメータを用いて, 拡張誘起電圧推定方 式でセンサレス運転する。

（4）駆動時のパラメータ同定：拡張誘起電圧推定方式 でセンサレス運転中に停止時に同定できなかった $\psi_{a}$ を同 定する。

〈5・2〉 停止時の特性高周波電流注入方式による初 期位置誤差の収束特性を図 3 に示す ${ }^{(9)}$ 。 $84^{\circ} ， 45^{\circ}$ あった初 期位置誤差が $0.1 \mathrm{~s}$ 以内に数度以下に収束している。この推 定位置を使用して，パラメータ同定を行った。

$d$ 軸モデル（(12), (13) 式）を用いたパラメータ同定で使 用する信号の波形を図 4 に示す。 $\gamma$ 軸電流指令を $10 \mathrm{~ms}$ ご とに -3.0A と $-4.0 \mathrm{~A}$ の間でステップ変化させている。定 常状態を想定した (12) 式に基づく同定では， $\gamma$ 軸電流指令 の変化後, $2.5 \mathrm{~ms}$ の間は同定動作を停止し, $\gamma$ 軸電流指令 の変化後に生じる電流, 電圧の過渡変化の信号を同定に使

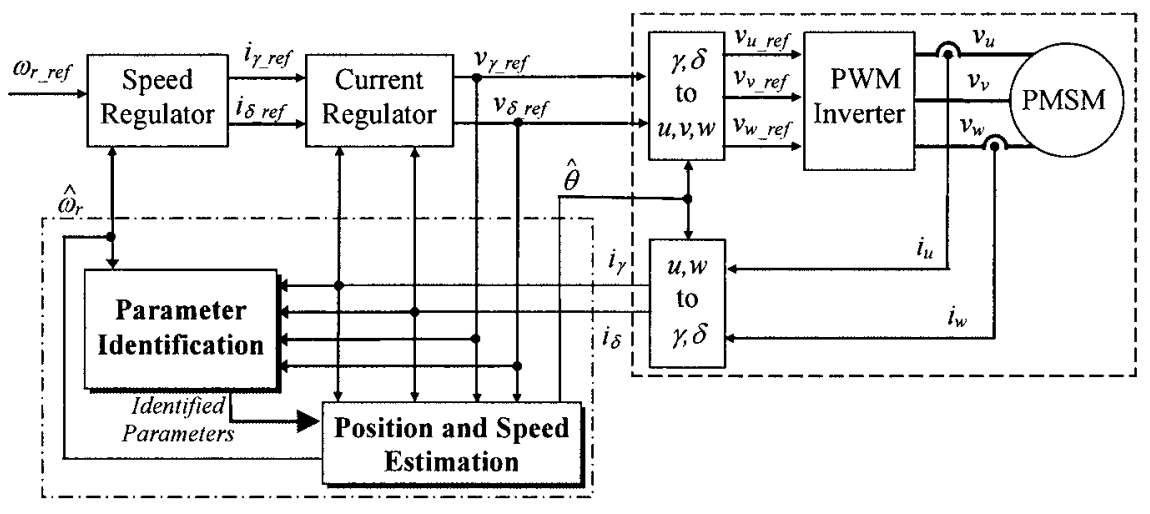

図 2 実験システムの構成図

Fig. 2. Block diagram of experimental system. 
表 1 実験システムのパラメータ

Table 1. Specifications of tested system.

\begin{tabular}{|l|l|l|l|}
\hline Number of pole pairs & 2 & Magnet flux-linkage $\psi_{a}(\mathrm{mWb})$ & 78.5 \\
\hline Rated speed $\left(\mathrm{min}^{-1}\right)$ & 2000 & $d$-axis inductance $L_{d}(\mathrm{mH})$ & 9.67 \\
\hline Rated phase current $(\mathrm{A})$ & 5.0 & $q$-axis inductance $L_{q}(\mathrm{mH})$ & 24.3 \\
\hline PWM frequency $(\mathrm{kHz})$ & 10 & Armature resistance $R_{a}(\Omega)$ & 0.824 \\
\hline DC link voltage $(\mathrm{V})$ & 150 & Resistance $R_{s}(\Omega)$ & 0.975 \\
\hline Dead-time $t_{d}(\mu \mathrm{s})$ & 5.0 & Voltage drop $\Delta V(\mathrm{~V})$ & 6.63 \\
\hline
\end{tabular}

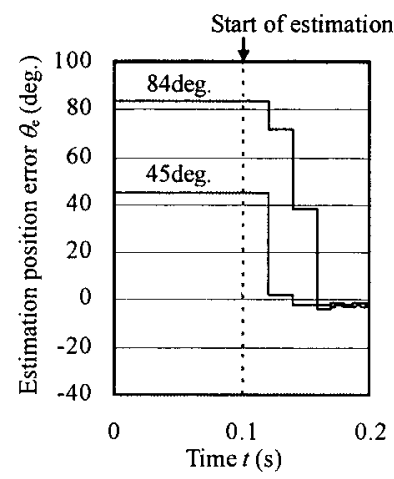

図 3 初期位置の推定特性

Fig. 3. Estimating characteristic of initial position.

用しないようにしている。(12) 式に基づく $R_{s}, \Delta V$ の同定 特性を図 5 に示す。 $t=0.05 \mathrm{~s}$ より同定を開始しており，図 の右端の矢印はオフラインで測定した表 1 の值を示してい る。同定の開始時点および図中の矢印の意味は他の同定特 性図に扔いても同様である。図 5 より， $R_{s}, \Delta V$ はともに 安定，かつ高速に同定できていることがわかる。

同定した $R_{s}$ を使用し，停止時の $d$ 軸モデル（(13) 式）と $q$ 軸モデルを用いた $d, q$ 軸インダクタンスと $\Delta V$ の同定特 性を図 6 に示す。ここで， $d$ 軸の同定信号は図 4 と同様で あり, $q$ 軸電流指令はモータが回転しないように $10 \mathrm{~ms}$ ご とに $-1.0 \mathrm{~A}$ と $1.0 \mathrm{~A}$ の間でステップ変化させている。図 6 より非常に早い収束特性が得られていることが確認できる。 $q$ 軸電流指令をステップ変化したとき, 若干の振動と騒音 が生じたが，図 6 のように高速のパラメー夕同定が可能な ため同定信号 $(q$ 軸電流 $)$ の印加期間は $50 \mathrm{~ms}$ 以下の短時 間でよい。

なお，同定時の電流值や電流変化幅は大きい方が同定精 度は向上するが，停止位置推定に誤差があった場合，モー タが回転する恐れがあるためそれらの值には制約がある。

$\langle\mathbf{5} \cdot \mathbf{3}\rangle$ 運転時の特性 停止時のパラメータ同定より $\Delta V$ が同定できたので, 電圧指令值とインバータの出力電圧 の誤差が無くなるように (2) 式の関係式に基づき三相の電 圧指令值（ $\left.v_{u_{\text {_rref }}}, v_{v_{-} r e f}, v_{w_{-} r e f}\right)$ を(24) 式のようにフィー ドフォワード補正し， $v_{u}^{*}, v_{v}^{*}, v_{w}^{*}$ を PWM 回路の入力とす る。これは一般にデッドタイム補償と呼ばれる補正である が，パラメー夕同定により補正する電圧值が決定される。 な技, 図 5 , 図 6 に示したように 3 つの $\Delta V$ の同定值が得 られるが，ここでは平均值を用いた。
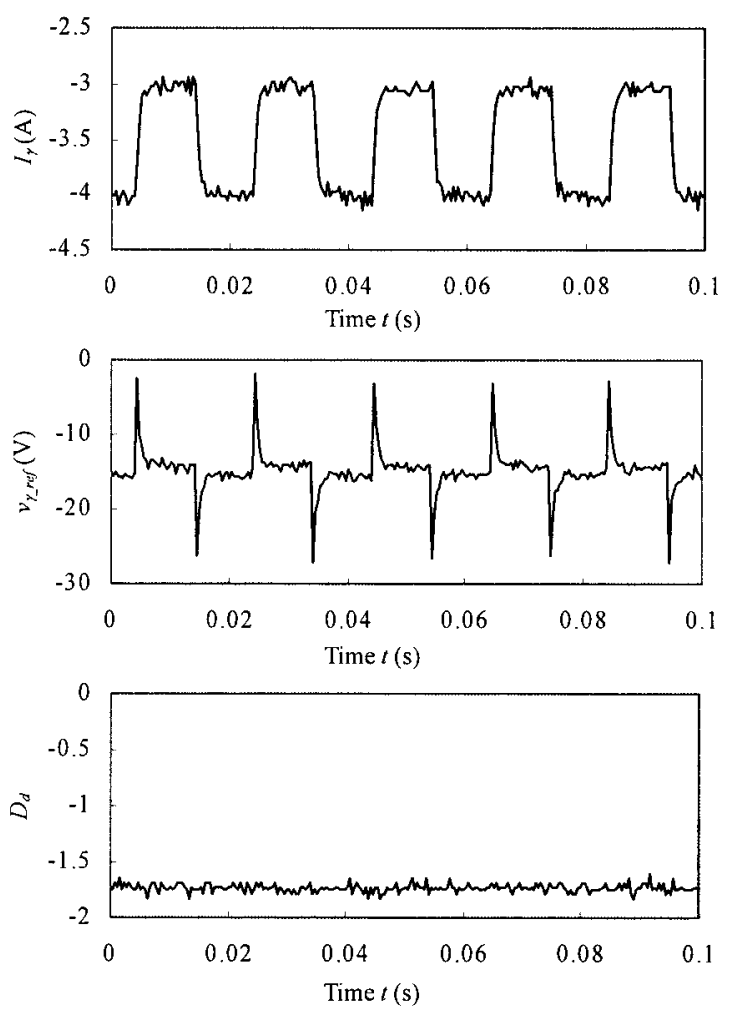

図 $4 \mathrm{~d}$ 軸モデルのパラメータ同定用信号

Fig. 4. Signals for parameter identification based on $d$ axis model.
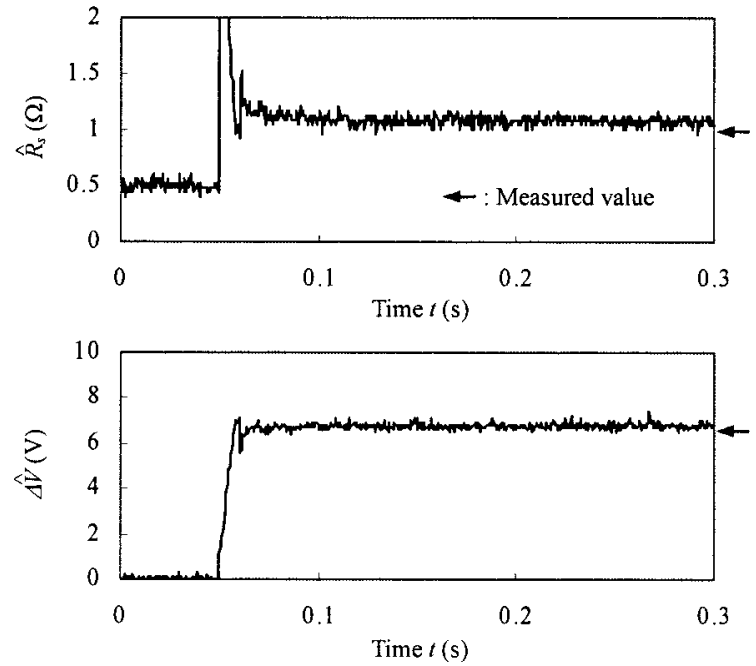

図 $5 R_{s}$ と $\Delta V$ の同定特性

Fig. 5. Identification characteristic of $R_{s}$ and tshape $\Delta V$.

$$
\left.\begin{array}{l}
v_{u}^{*}=v_{u \_r e f}+\Delta \hat{V} \cdot \operatorname{sgn}\left(i_{u}\right) \\
v_{v}^{*}=v_{v \_r e f}+\Delta \hat{V} \cdot \operatorname{sgn}\left(i_{v}\right) \\
v_{w}^{*}=v_{w_{-} r e f}+\Delta \hat{V} \cdot \operatorname{sgn}\left(i_{w}\right)
\end{array}\right\}
$$

$\Delta V$ の補正の効果および同定した $\Delta V$ の妥当性を検証する ため, 指令電圧と実際のモー夕電圧の比較結果を図 7 に示 す。ここで, 測定したインバータの出力電圧は線間電圧の基 本波実効值であり, 指令電圧は $V_{r e f}=\sqrt{\left(v_{d_{-} r e f}\right)^{2}+\left(v_{q_{-} r e f}\right)^{2}}$ 

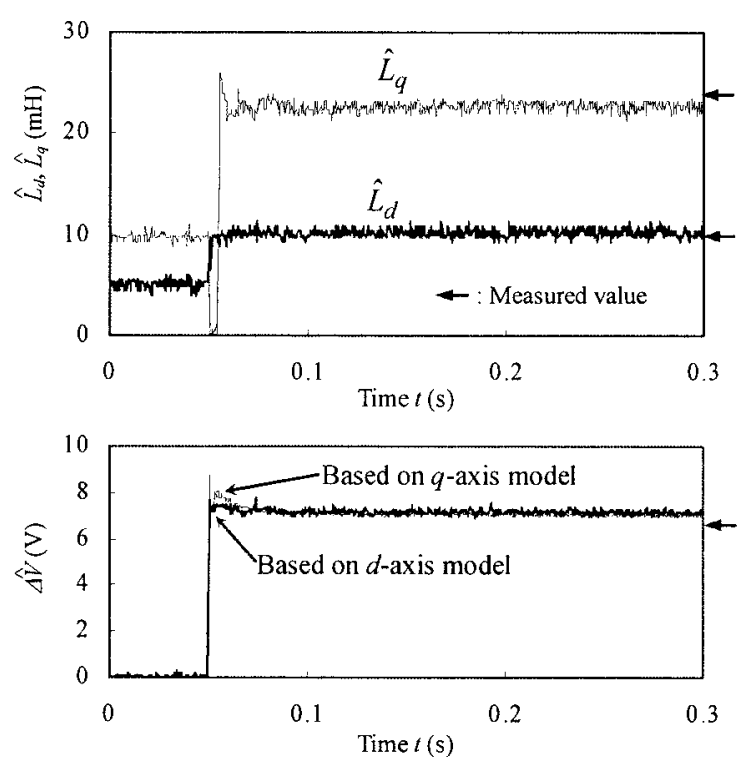

図 $6 d, q$ 軸インダクタンスと $\Delta V$ の同定特性

Fig. 6. Identification characteristic of $d, q$ inductances and $\Delta V$.

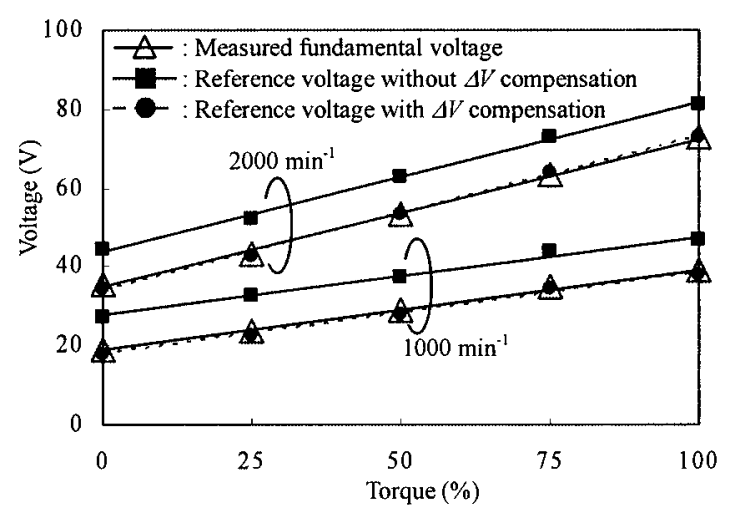

図 $7 \Delta V$ の補正の効果

Fig. 7. Effects of compensation of $\Delta V$.

で求めた值である。インバータ部の電圧降下が完全に補償 されていれば両者は一致する。図 7 に示すように同定した $\Delta V$ を用いて，(24) 式のように電圧指令值を補正すること で，指令值と実測值とが良く一致しており， $\Delta V$ の同定值 が適切であることが確認できた。これより同定した $\Delta V$ を 用いて電圧補正を行えばセンサレス制御に電圧指令值を使 用できる。

図 8 に停止時に同定したパラメータを使用し, 拡張誘起電 圧推定方式のセンサレス制御を行ったときの無負荷運転特 性を示す。ここでは，速度指令值を $2 \mathrm{~s}$ 毎に $1800 \mathrm{~min}^{-1}$ と $2000 \mathrm{~min}^{-1}$ の間でステップ変化している。過渡時に多少の 速度推定誤差, 位置推定誤差が生じているが，ほぼ零に収束 し，良好なセンサレス駆動が実現できている。図 9 には負荷 時に低速加減速運転を行ったときの特性を示す。負荷装置 の制約により負荷トルクは $400 \mathrm{~min}^{-1}$ で $100 \%, 200 \mathrm{~min}^{-1}$ で約 $50 \%$ となっている。図 8 に比べ速度推定誤差，位置推
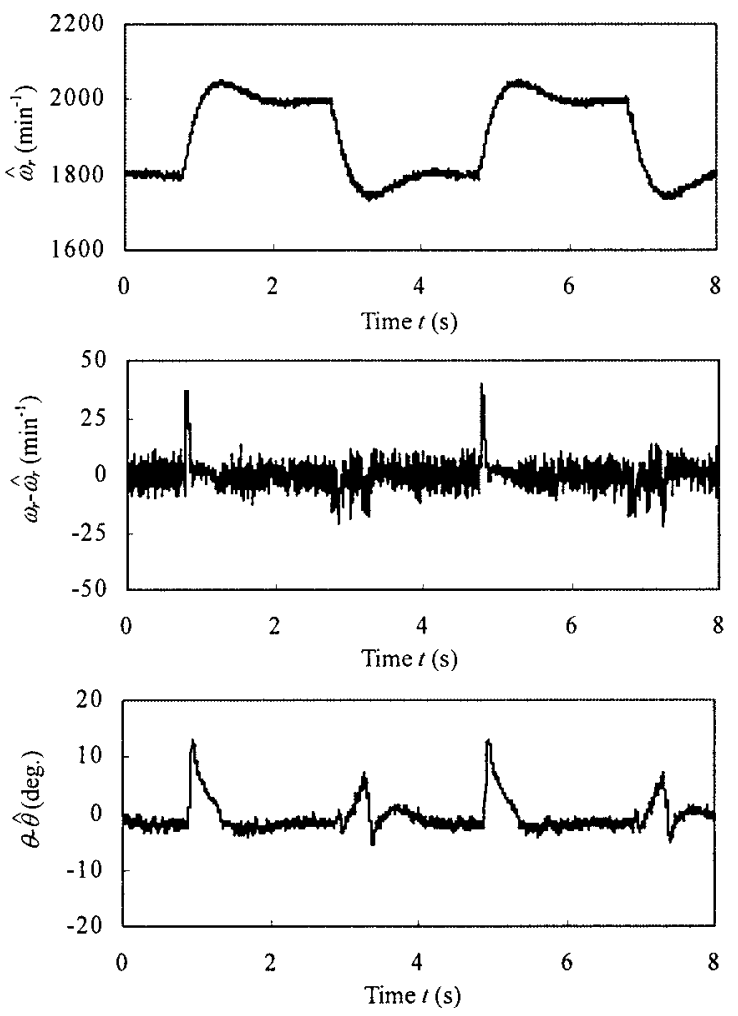

図 8 同定パラメータを用いたセンサレス制御の特性 (高速無負荷運転)

Fig. 8. Performance of sensorless control using identified parameters. (High speed operation without load).
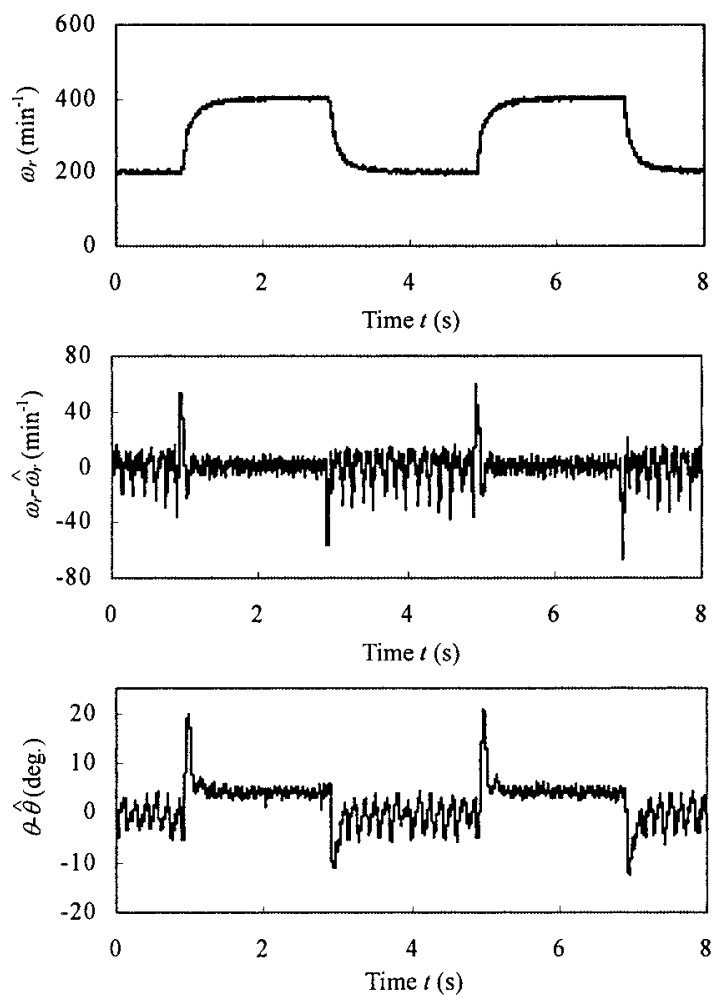

図 9 同定パラメータを用いたセンサレス制御の特性 (低速負荷運転)

Fig. 9. Performance of sensorless control using identified parameters. (Low speed operation with load). 
Table 2. Average of estimation position error.

\begin{tabular}{|c|c|c|c|c|c|c|}
\hline Load torque & No load & $20 \%$ & $40 \%$ & $60 \%$ & $80 \%$ & $100 \%$ \\
\hline $\begin{array}{c}\text { Average of } \theta_{e} \text { at } \\
200 \mathrm{~min}^{-1}(\mathrm{deg} .)\end{array}$ & 0.76 & -1.24 & 1.09 & 2.97 & 4.79 & 6.71 \\
\hline $\begin{array}{c}\text { Average of } \theta_{e} \text { at } \\
2000 \mathrm{~min}^{-1}(\mathrm{deg} .)\end{array}$ & -1.27 & 0.13 & 1.26 & 2.63 & 3.91 & 5.65 \\
\hline
\end{tabular}

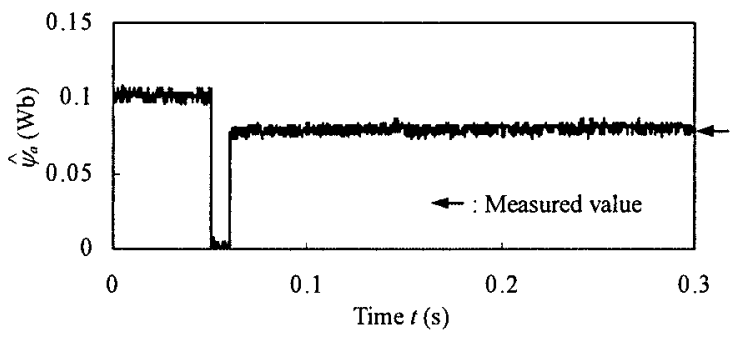

図 10 磁石磁束の同定特性

Fig. 10. Identification of magnet flux-linkage.

定誤差の振動が大きくなっているがセンサレス運転が実現 できている。なお，(24) 式による $\Delta V$ 補正を行わなかった場 合は $200 \mathrm{~min}^{-1}$ におけるセンサレス運転は不可能であった。

表 2 に低速および定格速度における位置推定誤差の平均 值を示す。負荷の増加とともに位置推定誤差が増加してい ることがわかる。電流増加による磁気飽和の影響で $q$ 軸イ ンダクタンスは表 1 の值から定格負荷時には約 $20 \mathrm{mH}$ に減 少するため, 負荷増加による $L_{q}$ の減少が位置推定誤差の主 な原因と考えられる。

図 8 の運転状態において, (14) 式の同定モデルで磁石磁 束 $\psi_{a}$ を同定した結果を図 10 に示す。なお， $\Delta V$ の補正を 行っているため, (14) 式の同定モデルにおいて $\Delta V$ の項は 無視している。 $\psi_{a}$ が高速かつ正確に同定できていることが わかる。

\section{6. あとがき}

本論文ではインバータを含めたモータモデルを構築し， そのモデルパラメータを停止時に位置センサレスで同定す ることで，パラメータの事前情報を必要としないセンサレ ス制御システムを提案した。停止時および駆動時に適切な 同定モデルを用いることで全てのパラメータが安定にかつ 素早く同定できることを実験で確認した。また，同定した インバータの電圧降下を用いた電圧補正の効果や同定した パラメータを用いて拡張誘起電圧推定方式のセンサレス制 御が実現できることも実験で確認した。なお，提案手法は リラクタンスモータの制御システムにも適用できる。本論 文では，停止時にセンサレス制御で用いるパラメータを同 定したが，モータパラメータは運転中に変化する。特に $L_{q}$ は磁気飽和で変化し電流依存性があるため, より高精度な センサレス制御の実現には $L_{q}$ の磁気飽和特性の同定やオ ンラインパラメータ同定が必要であり, 今後の検討課題で ある。

\section{文献}

(1) S. Morimoto, Y. Takeda, and T. Hirasa: "Parameter Measurement of PM Motor in dq Equivalent Circuit", T. IEE Japan, Vol.113-D, No.11, pp.1330 1331 (1993-11) (in Japanese)

森本茂雄・武田洋次・平紗多賀男：「PM モー夕の dq 等価回路定数 測定法」, 電学論 D, 113, 11, pp.1330-1331 (1993)

(2) T. Takeshita, A. Usui, A. Sumiya, and N. Matsui: "Parameter Measurement of Sensorless Permanent Magnet Synchronous Motor", T. IEE Japan, Vol.119-D, No.10, pp.1184-1191 (1999-10) (in Japanese)

竹下隆晴・百井 明・角谷敦之・松井信行：「センサレス PMSM の パラメータ計測法」, 電学論 D, 119, 10, pp.1184-1191 (1999-10)

(3) S. Hagiwara, Y. Ohmori, and H. Kobayashi: "Identification Methods for Permanent Magnet Motor's Parameters", Proc. of the 2000 JIAS Conf., pp.175178 (2000) (in Japanese)

萩原茂教・大森洋一・小林弘和：「IPM モー夕のモー夕定数同定方 法」, 平成 12 電気学会産業応用部門大会, pp.175-178 (2000)

(4) S. Ichikawa, M. Tomita, S. Doki, and S. Okuma: "Sensorless Control of Synchronous Motors Using an On-line Parameter Identification Method Based on System Identification Theory", Proc. of the 2004 JIAS Conf., pp.I495-I-498 (2004) (in Japanese)

市川真士・冨田睦雄・道木慎二・大熊 繁 :「システム同定理論に基 づくオンラインパラメータ同定法を用いた同期電動機のセンサレス 制御」, 平成 16 年電気学会産業応用部門大会, pp.I-495-I-498 (2004)

(5) S. Morimoto, M. Kozaki, and Y. Takeda: "Parameter Identification of PM Motor System at Standstill", IEEJ Trans IA., Vol.123, No.9, pp.1081-1082 (2003-9) (in Japanese)

森本茂雄・神前政幸・武田洋次：「PM モータシステムの停止時にお けるパラメータ同定」, 電学論 D, 123, 9, pp.1081-1082 (2003-9)

(6) A. Shimmei, S. Morimoto, and Y. Takeda: "On-line Parameter Identification Method of PM Motor System", 2004 National Convention Record, IEE Japan, No.4-118 (2004) (in Japanese)

神名玲秀. 森本茂雄・武田洋次：「PM モータシステムのオンライン パラメー夕同定法」, 平成 16 電学全大, No.4-118 (2004)

(7) S. Morimoto, K. Kawamoto, and Y. Takeda: "Position and Speed Sensorless Control for IPMSM Based on Estimation of Position Error", T. IEE Japan, Vol.122-D, No.7, pp.722-729 (2002-7) (in Japanese)

森本茂雄・河本啓介・武田洋次：「推定位置誤差を利用した IPMSM の位置・速度センサレス制御」, 電学論 D, 122, 7, pp.722-729 (2002-7)

(8) S. Ichikawa, Z. Chen, M. Tomita, S. Doki, and S. Okuma: "Sensorless Controls of Salient-Pole Permanent Magnet Synchronous Motors Using Extended Electromotive Force Models", T. IEE Japan, Vol.122-D, No.12, pp.1088-1096 (2002-12) (in Japanese)

市川真士・陳 志謙・冨田睦雄 ·道木慎二 · 大熊 繁：「拡張誘起電 圧モデルに基づく突極型永久磁石モー夕のセンサレス制御」, 電学論 D, 122, 12, pp.1088-1096 (2002-12)

(9) M. Tetsuya, S. Morimoto, and Y. Takeda: "Position Sensorless Control for IPMSM at Whole Speed Range Based on Estimated Position Error", Proc. of the 2003 JIAS Conf., pp.175-178 (2003) (in Japanese)

松山哲也・森本茂雄・武田洋次：「軸䛊差推定に基ついた IPMSM の 全速度領域における位置センサレス制御」, 平成 15 電気学会産業応 用部門大会, pp.587-590 (2003)

(10) S. Shinnaka, A. Toba, and D. Zhang: "Control Technologies for Sensorless Drive of Permanent Magnet Synchronous Motors", Proc. of the 2004 JIAS Conf., 1-S15-4 (2004) (in Japanese)

新中新二・鳥羽章夫 · 張東寧 : 「永久磁石同期電動機の制御技術」, 平 成 16 年電気学会産業応用部門大会, 1-S15-4 (2004)

(11) N. Urasaki, T. Senjyu, K. Uezato, and T. Funabashi: "On-Line Dead-Time Compensation Method for Permanent Magnet Synchronous Motor Drive", Proc. of the 2002 JIAS Conf., pp.1491-1496 (2002) (in Japanese) 浦崎直光・千住智信 ・上里勝実・舟橋俊久：「PM モータドライブの オンラインデッドタイム補償法」, 平成 14 電気学会産業応用部門大 会, No.292, pp.1491-1496 (2002)

12) A. Shimmei, S. Morimoto, M. Sanada, and Y. Takeda: "Parameter Identification and Position Sensorless Control for IPMSM", Papers of Technical Meeting on SPC, IEE Japan, SPC-05-29 (2005) (in Japanese) 神名玲秀·森本茂雄・真田雅之・武田洋次：「埋込磁石同期モー夕の パラメータ同定と位置センサレス制御」, 電気学会半導体電力变換器 研究会, SPC-05-29 (2005) 
森 本 茂 雄 (上級会員) 1959 年 6 月 28 日生。1 984 年 3 月

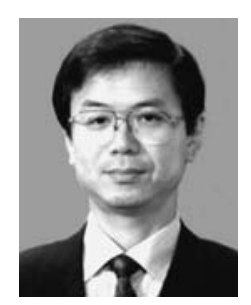
大阪府立大学大学院修士課程修了。1988 年 7 月 大阪府立大学助手, 1994 年 4 月同助教授, 現在に 至る。工学博士。主としてモータドライブシステ ム, モーションコントロールの研究に従事。IEEE, 計測自動制御学会, システム制御情報学会, パワー エレクトロニクス学会各会員。

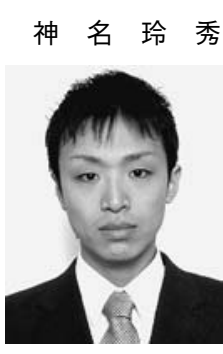

(学生員) 1980 年 5 月 28 日生。 2005 年 3 月大 阪府立大学大学院工学研究科電気・情報系専攻博 士前期課程修了。同年 4 月トヨ夕自動車（株）入 社。在学中は, 永久磁石同期モータのオンライン パラメータ同定とセンサレス制御に関する研究に 従事。

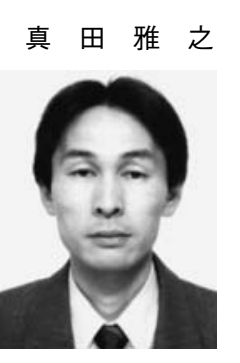

（正員） 1966 年 6 月 1 日生。1994 年 3 月大阪府 立大学大学院工学研究科博士後期課程修了。同年 4 月同大学助手, 1997 年 7 月同講師, 現在に至る。 工学博士。この間, 主としてリニアモータ, 電磁 界解析の研究に従事。IEEE, 日本 AEM 学科, パ ワーエレクトロニクス学会各会員。

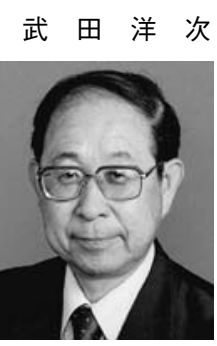

(上級会員) 1943 年 11 月 10 日生。1968 年 3 月 大阪府立大学大学院修士課程修了。同年 4 月同大 学助手, 1993 年 4 月同教授, 現在に至る。工学 博士。主として, 電動機可変速制御システム, リ ニアアクチュエータの研究に従事。IEEE, 電気情 報通信学科, 計測自動制御学会, システム制御情 報学会, パワーエレクトロニクス学会各会員。 